OPEN ACCESS

Edited by:

Naoki Iwamoto,

Nagasaki University Hospital,

Japan

Reviewed by:

Alakendu Ghosh,

Dept. of Health \& Family Welfare,

Peng Zhang.

Huazhong University of Science and

Technology, China

Hyung-Mun Yun,

Kyung Hee University, South Korea

Shoichi Fukui,

Nagasaki University, Japan

${ }^{*}$ Correspondence:

Guo-Min Deng

gmdeng@hust.edu.cn

Specialty section: This article was submitted to Autoimmune and

Autoinflammatory Disorders,

a section of the journal

Frontiers in Immunology

Received: 30 March 2021 Accepted: 09 June 2021

Published: 23 June 2021

Citation:

Zuo Y and Deng G-M (2021)

FC Gamma Receptors as

Regulators of Bone Destruction

in Inflammatory Arthritis.

Front. Immunol. 12:688201. doi: 10.3389/fimmu.2021.688201

\section{Fc Gamma Receptors as Regulators of Bone Destruction in Inflammatory Arthritis}

\author{
Yuyue Zuo and Guo-Min Deng* \\ Department of Rheumatology and Immunology, Union Hospital, Tongji Medical College, Huazhong University of Science and \\ Technology, Wuhan, China
}

Bone erosion is one of the primary features of inflammatory arthritis and is caused by excessive differentiation and activation of osteoclasts. Fc gamma receptors (FcyRs) have been implicated in osteoclastogenesis. Our recent studies demonstrate that jointdeposited lupus IgG inhibited RANKL-induced osteoclastogenesis. FcyRl is required for RANKL-induced osteoclastogenesis and lupus IgG-induced signaling transduction. We reviewed the results of studies that analyzed the association between FcyRs and bone erosion in inflammatory arthritis. The analysis revealed the dual roles of FcyRs in bone destruction in inflammatory arthritis. Thus, lgG/FcyR signaling molecules may serve as potential therapeutic targets against bone erosion.

Keywords: FcyRs, autoantibodies, osteoclasts, bone erosion, inflammatory arthritis

\section{INTRODUCTION}

Inflammatory arthritis is a group of diseases characterized by joint inflammation and bone damage. About $0.1 \%$ of adults develop inflammatory arthritis annually (1). Rheumatoid arthritis (RA) is a chronic autoimmune disease characterized by progressive synovitis and bone destruction, causing irreversible joint damage and disability (1-4). Bone erosion is the central hallmark of RA in ultrasonography identification $(5,6)$. Anti-citrullinated protein antibodies (ACPAs) are considered to be among the leading risk factors for bone destruction in RA (7). Ankylosing spondylitis (AS) and psoriatic arthritis (PsA) are other common inflammatory arthritis diseases with bone destruction $(8,9)$.

Systemic lupus erythematosus (SLE) is a chronic autoimmune disease characterized by multiorgan tissue damage and high levels of autoantibodies in the serum (10). Arthritis is a common clinical manifestation with a prevalence of 69 to $95 \%$ in patients with SLE (11). However, only 4 to $6 \%$ of patients with SLE arthritis display bone erosion on plain radiographs (12-14). As to ACPA positive SLE patients, which are also called rhupus patients, they often overlapped clinical features and fulfilled American College of Rheumatology (ACR) criteria for RA classification $(15,16)$. It is still unclear why lupus arthritis without ACPA lacks bone destruction. Recently, FcyRs have been reported to exert a regulatory effect on osteoclastogenesis (17-25). Our recent study demonstrated that joint-deposited lupus IgG triggered arthritis without bone erosion in mice and lupus IgG inhibited osteoclastogenesis induced by receptor activator of nuclear factor kappa-B ligand (RANKL). FcyRI exerted an inhibitory effect of lupus IgG on RANKL-induced osteoclastogenesis (26). Our study suggests that FcyR could function as critical regulators of inflammatory arthritis. 
Here, we review the published studies and demonstrate the association between the $\mathrm{Fc} \gamma \mathrm{R}$ and bone erosion in inflammatory arthritis.

\section{Fc $\gamma$ RECEPTOR FAMILY}

FcyRs are receptors for the constant $(\mathrm{Fc})$ region of IgG; these are expressed widely on the surface of immune cells, including monocytes, macrophages, neutrophils, dendritic cells (DCs), B cells, natural killer cells, and mast cells. Four different classes of Fc $\gamma$ Rs have been identified in mice, namely Fc $\gamma$ RI, Fc $\gamma$ RIIB, Fc $\gamma$ RIII, and FcyRIV (27-29). The human and primate Fc $\gamma R$ classifications are more complex. Humans possess six classic FcyRs with different IgG binding capacity and downstream signaling pathways: Fc $\gamma \mathrm{RI}$ (CD64), Fc $\gamma$ RIIA (CD32A), Fc $\gamma$ RIIB (CD32B), Fc $\gamma$ RIIC (CD32C), FcyRIIIA (CD16A), and FcyRIIIB (CD16B), which are encoded by genes FCGR1A, FCGR2A, FCGR2B, FCGR2C, FCGR3A, and FCGR3B, respectively (Figure 1).

The affinity of Fc $\gamma$ Rs for IgG depends on the type of Fc $\gamma \mathrm{R}$ and IgG isotypes (30-36). Fc $\gamma R I$ is the only known high-affinity Fc $\gamma \mathrm{R}$ $\left(10^{8}-10^{9} \mathrm{M}^{-1}\right)$ with a restricted isotype specificity. In contrast, Fc $\gamma$ RII and Fc $\gamma$ RIII have a low affinity for IgG (about $10^{6} \mathrm{M}^{-1}$ ) with a broader isotype binding pattern $(31,32)$. Fc $\gamma$ RIV is a novel receptor conserved across all mammalian species with an intermediate affinity $\left(10^{7} \mathrm{M}^{-1}\right)$ and restricted subclass specificity $(29,37)$. FcrRIIIA is engaged by IgG1 and IgG2,

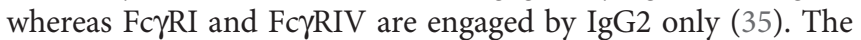

affinity of mouse Fc $\gamma$ Rs is significantly higher compared with their corresponding human FcyRs (36).

Fc $\gamma$ Rs are divided into activating and inhibitory receptors and coexpressed on the same cell (38). Activating Fc $\gamma$ Rs, including Fc $\gamma R I$ and Fc $\gamma$ RIII, contain an immunoreceptor tyrosine-based activation (ITAM) in intracellular structure and transmit their signals via the ITAM, which recruits spleen tyrosine kinase (Syk) (39). Fc $\gamma$ RIIB is the only known inhibitory Fc $\gamma R$ with an immunoreceptor tyrosine-based inhibitory motif (ITIM) in its intracytoplasmic domain (40). The phosphorylation of ITIM counteracts the signals mediated by activating Fc $\gamma$ Rs (41-43). FcyRIIB is expressed widely on B cells, macrophages, and mast cells and downregulates several cellular functions, such as B-cell activation and mast cell degranulation (44). The activating-toinhibitory (A/I) ratio on the same cell acts as the specific checkpoint for the arrest or progression of an immune response. Surprisingly, when monomeric or low-affinity immune complexes bind to activating FcyRs, the normally activating ITAM domain cannot induce co-aggregation of activating receptors, thereby partially phosphorylating the ITAM domain. Thus, partial tyrosine phosphorylation of ITAM by Src family kinases may result in the recruitment of inhibitory SHIP. This is called inhibitory ITAM (ITAMi) signal and is important in maintaining immune homeostasis (45-47).

Unlike other activating Fc $\gamma$ Rs, Fc $\gamma$ RII proteins do not require the common FcR $\gamma$-chain for stable expression or function. They all have signaling motifs in their intracellular cytoplasmic domains (48). All the above Fc $\gamma$ Rs are transmembrane

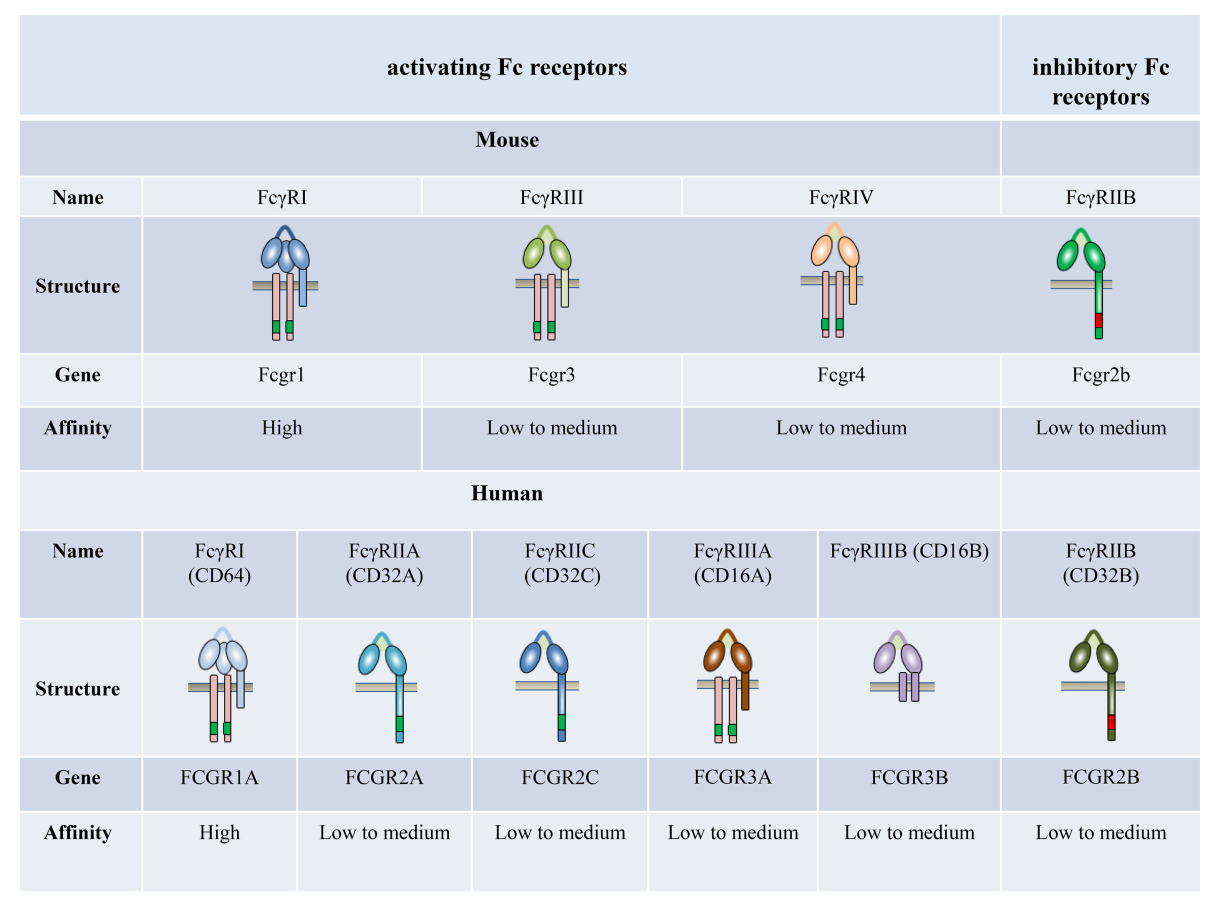

FIGURE 1 | The family of classical Fc receptors for IgG. Schematic representations of FcyRs with respect to the cell membrane (brown bar), in complex with their respective signaling subunits. Mouse and humans have one high-affinity receptor, FcyRl; all other FcyRs have a low-to-medium affinity for the antibody Fc fragment. 
glycoproteins, except for human Fc $\gamma$ RIIIB, which is expressed on neutrophils and is a glycophosphatidylinositol (GPI)-anchored protein $(49,50)$. The mechanisms by which Fc $\gamma$ RIIIB transduces signals are still unknown (51).

\section{FcyRs AND ARTHRITIS}

During autoimmune diseases, such as RA and SLE, the autoantibodies and immune complexes cause inflammation via FcR aggregation (52). The altered expression of Fc $\gamma$ Rs on immune cells in the circulation and synovium of RA patients is the first indication of their involvement in inflammation (5360). The absence of all FcyRs does not affect the number of osteoclast precursors or their osteoclastogenic potential. However, it reduces joint inflammation and bone erosion during inflammatory arthritis (61). Fc $\gamma$ RIIB is particularly critical for maintaining the balance of an efficient inflammatory response or countering unwanted autoimmunity attacks. Multiple clinical studies have shown that FcyRIIB is a reliable biomarker for SLE susceptibility in different ethnic groups. Fc $\gamma$ RIIB and its signaling pathways represent a vital checkpoint in peripheral and central tolerance and in controlling the development of autoreactive antibodies (62).

In addition to the altered expression of Fc $\gamma$ Rs, genetic variants associated with related single-nucleotide polymorphisms (SNPs) in populations with RA and lupus arthritis have been reported. Several genes encoding Fc $\gamma$ Rs that alter the affinity of Fc $\gamma$ Rs for IgGs have been described in several RA populations. In particular, some of these, such as the hFc $\gamma$ RIIa-R131 variant, which is related to an increased risk of developing RA, even influence the susceptibility to RA development and the response to treatment (63-70). In addition, an association between lupus arthritis and the FCGR2A as well as FCGR3A low copy number genotypes has been observed in Taiwan patients with SLE. The FCGR3A low copy number genotype was significantly enriched in patients with SLE having arthritis (71-73). Moreover, a metaanalysis revealed the association of the Fc $\gamma$ RIIa-R131 allele with SLE, especially in African Americans, whereas the Fc $\gamma R I I I a-F 176$ allele was associated with SLE in Caucasians and other groups (74). Furthermore, Tsang et al. demonstrated the association between low-affinity Fc $\gamma \mathrm{R}$ polymorphisms and susceptibility to SLE (75).

Studies using $F c \gamma R$ gene-deficient mice have greatly enhanced our understanding of the role of Fc $\gamma$ Rs in inflammatory arthritis $(76,77)$. The lack of activating Fc $\gamma$ Rs alleviates the disease severity in arthritis models (78-81). In different disease phases of inflammatory arthritis, the individual activating Fc $\gamma$ Rs have different significance $(36,61,82-86)$. In the absence of Fc $\gamma R I$, Fc $\gamma$ RIIB, and Fc $\gamma$ RIIIA, Fc $\gamma R I V$ is sufficient to induce arthritis alone (35). In contrast with activating Fc $\gamma$ Rs, the inhibitory FcyRIIB suppresses inflammation by inhibiting the activating signaling, as well as providing negative feedback on the production of autoantibodies by B cells (87-92).

Autoantibodies and their immune complexes play a central role in shaping a pro-inflammatory environment. Indeed, complexes of ACPA and rheumatoid factor (RF) induce the production of potent inflammatory cytokines (93-96). This effect is predominantly mediated by $\mathrm{Fc} \gamma \mathrm{R}$ signaling on macrophages $(51,97)$. Tumor necrosis factor (TNF)- $\alpha$, in combination with cytokines interleukin (IL)-4 and IL-13, downregulates Fc $\gamma$ Rmediated function by decreasing the expression of activating Fc $\gamma$ Rs, suggesting that downregulated activating Fc $\gamma$ Rs might have an anti-inflammatory effect (98).

The Fc receptors on white blood cells are essential for effective phagocytosis of immune complexes and bacteria. Moreover, Fc $\gamma R I$ is upregulated during infection. Fc $\gamma R I$ (CD64) has previously been reported to distinguish systemic infections from inflammatory autoimmune diseases and viral infections. Patients without inflammatory and infectious conditions, such as osteoarthritis, have a lower level of neutrophil Fc $\gamma$ RI than those with infections (99-104). Oppegaard et al. investigated the use of Fc $\gamma R$ I in discerning septic arthritis from inflammatory joint disease and found that FcyRI is highly specific for infectious diseases, including septic arthritis. However, its sensitivity is poor in local infections (104). Although distinct meta-analyses have confirmed this, more large prospective studies need to be conducted to verify several cut-off values reported in the neutrophil Fc $\gamma$ RI test in the clinical setting $(105,106)$.

Human and murine activating Fc $\gamma$ Rs are not functionally equivalent. A few studies performed in transgenic mice expressing human Fc $\gamma$ Rs examined their involvement in inflammatory arthritis (107). The results confirmed that the expression of the human FcrRIIA is associated with spontaneous autoimmune inflammation, with a crucial role in autoimmune diseases (92).

\section{FcyR ROLE IN BONE EROSION}

\section{Osteoclast Activation and Differentiation}

Bone balance depends on a dynamic regulation of bone formation and resorption, which are predominantly mediated by osteoblasts and osteoclasts, respectively $(108,109)$. Enhanced osteoclast activity could result in severe bone destruction as exemplified in autoimmune inflammatory diseases such as RA, whereas defective osteoblast differentiation causes diseases with a high bone mass, including osteopetrosis. Osteoclasts are the only bone-resorbing cells and play a central role in bone erosion. Osteoclasts are derived from multinucleated progenitors of the monocyte/macrophage family and are the link between immune and bone systems. RANK and RANKL are critical factors that together regulate osteoclast functions. In addition, macrophage colony-stimulating factor (M-CSF) is an essential cytokine in osteoclastogenesis (109-111). RANKL is majorly secreted by osteoblasts, osteocytes, T cells, and endothelial cells. And osteocytes express a much higher amount of RANKL required for osteoclastogenesis than osteoblasts $(112,113)$. The most important negative regulator of RANKL is the decoy receptor osteoprotegerin (OPG), which inhibits osteoclastogenesis by preventing RANKL-RANK interaction. The RANKL-RANKOPG system modulates bone homeostasis by regulating 
osteoclasts (114). Osteoblasts and osteocytes also produce OPG to suppress osteoclastogenesis by masking RANKL signaling $(115,116)$. RANKL initiates osteoclastogenesis by inducing nuclear factor of activated T-cells, cytoplasmic 1 (NFATc1), via TNF receptor-associated factor 6 (TRAF6) and c-Fos pathways (117) (Figure 2). NFATc1 is the master transcription factor for pro-osteoclastogenic genes. In addition, several proinflammatory cytokines produced by innate immune cells and $\mathrm{T}$ cells, such as TNF $\alpha$, IL-17, IL-1, and IL-6, stimulate osteoclastogenesis directly or indirectly (118).

\section{FcyRs and Osteoclastogenesis}

Apart from the M-CSF and RANKL signaling, an ITAM costimulatory signal provided by the accessory protein for RANKL-RANK is required for osteoclastogenesis (119). Takayanagi et al. first reported that the activation of NFATc1 was insufficient for terminal differentiation of monocytes/ macrophages into osteoclasts; calcium signals and calcineurin activation are essential for this process (117, 120). Calcium signals in myeloid cells are provided by the ITAM-bearing proteins, Fc receptor $\gamma$ subunit, and its functional analog DNAX activation protein of $12 \mathrm{kDa}$ (DAP12). Both the accessory proteins are intracellular adaptor molecules and play a crucial function in transducing the costimulatory signals for
RANKL (121). Mice lacking the accessory proteins display a severe osteopetrotic phenotype with deficient osteoclast function (122).

$\mathrm{FcR} \gamma$-chain is associated with immunoglobulin (Ig)-like receptors, such as osteoclast-associated receptor (OSCAR) and paired Ig-like receptor-A (PIR-A) (Figure 2). DAP12 is associated with its signaling counterpart, triggering receptor expressed on myeloid cell-2 (TREM-2), and signal-regulatory protein $\beta 1$ (SIRP $\beta 1$ ), which are expressed on the cell membrane of osteoclast precursors and are essential for the communication between osteoclast precursors $(33,123)$. Activation of RANKLRANK rapidly phosphorylates the ITAM motifs and recruits the protein kinase Syk, subsequently activating multiple downstream signaling cascades, such as phospholipase $\mathrm{C} \gamma$ (PLC $\gamma$ ) and Bruton's tyrosine kinase (BTK) as well as Tec kinases. They all enhance the effects of RANKL-signaling by augmenting the calcium influx required for the activation of NFATc1. NFATc1 subsequently migrates to the nucleus, where it binds to its gene promoter and triggers an auto-amplifying feedback loop $(124,125)$.

Osteoclasts and their precursors express Fc $\gamma \mathrm{R}$ (126), whereas Fc $\gamma$ RI, Fc $\gamma$ RIIB, and Fc $\gamma$ RIIIA are significantly upregulated during human ex vivo osteoclastogenesis (127). Blocking of the $\mathrm{FcR}$ and deleting the $\mathrm{Fc \gamma R}$ gene reduce osteoclastogenesis

FIGURE 2 | Overview of the osteoclast signaling network. A schematic representation of ITAM-mediated costimulatory signal in the RANKL-induced TRAF6 signaling pathway of osteoclast differentiation. In osteoclast precursors, phosphorylation of ITAM stimulated by immunoreceptors and RANKL-RANK interaction recruits the Syk family kinases, thus activating phospholipase C $\gamma$ (PLC $\gamma$ ), Bruton's tyrosine kinase (BTK), as well as Tec kinases. They augment the calcium influx required for the activation of NFATc1. NFATc1 subsequently migrates to the nucleus, where it binds to its gene promoter and triggers an auto-amplifying feedback loop. Calcium signals in osteoclast precursors are provided by the ITAM-bearing proteins, Fc receptor $\gamma$ subunit, and its functional analog DNAX activation protein of $12 \mathrm{kDa}$ (DAP12). FcR $\gamma$-chain is associated with the immunoglobulin (lg)-like receptors, such as osteoclast-associated receptor (OSCAR) and paired lg-like receptor-A (PIR-A). DAP12 is associated with its signaling counterpart, triggering receptor expressed on myeloid cell-2 (TREM-2), and signal-regulatory protein $\beta 1$ (SIRP $\beta 1$ ). 
stimulated by IgG complexes on osteoclast precursor cells (25). Although Fc $\gamma$ Rs are required for osteoclastogenesis and bone resorption in inflammatory disorders, their specific role in bone homeostasis is not completely understood.

\section{FcyRs and Bone Erosion}

Costimulatory signals mediated by the ITAM motif cooperate with RANKL for bone homeostasis, suggesting the link between ITAM-harboring adaptors Fc $\gamma$ Rs and bone erosion (117). As an important link binding the bone system and immune system, FcyRs are not only receptors for the Fc portion of IgG but are also costimulatory molecules for RANKL-induced osteoclastogenesis $(119,121)$. Bone damage has been reported in seropositive RA patients before clinical disease onset, highlighting that osteoclastogenesis is independent of joint inflammation (128). This finding challenged the concept that inflammation is the primary trigger for bone erosion in inflammatory arthritis and indicated that bone loss might precede inflammation (129).

The expression of Fc $\gamma$ receptors on osteoclast precursor cells and mature osteoclasts has been measured. FcyRI and FcyRIII are primarily expressed on human preosteoclasts, whereas the inhibitory FcyRIIB is majorly expressed on mature osteoclasts (127). Under physiological conditions, activating Fc $\gamma R I$ and FcyRIV in mice does not have a major role in bone characteristics and osteoclast development (22). Bone homeostasis is not significantly different in mice with Fc $\gamma \mathrm{RI}$ or IV deficiency compared with wild mice (17). In addition, the deficiency of FcyRIIB does not affect osteoclastogenesis (23). Activating FcyRs transmit the positive signal. In contrast, FcyRIII functions as an inhibitory receptor in the differentiation of osteoclast precursor cells under physiological conditions. Fc $\gamma$ RIII deprives the FcR $\gamma$ subunit's availability for other Ig-like receptors activating receptors, such as PIR-A and OSCAR, thus transmitting an ITAM-mediated inhibitory signal for osteoclastogenesis (130). Naive Fc $\gamma \mathrm{RIII}^{-/-}$ mice have increased osteoclast numbers and an osteoporotic phenotype (22).

The relative importance of various Fc $\gamma$ Rs in osteoclastogenesis changes in the inflammatory arthritis microenvironment. Studies demonstrated that the stimulation of Fc $\gamma R I$ and FcyRIV increases both osteoclast differentiation and function both in vitro and in vivo

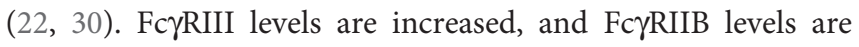
decreased on bone marrow cells from mice with collagen-induced arthritis (CIA), indicating that FcyRIII induces osteoclastogenesis under inflammatory conditions (22). Furthermore, human RA patients with the FcrRIIIa-158V allele endure severe bone erosion compared with patients with the FcrRIIIa-158F allele $(131,132)$.

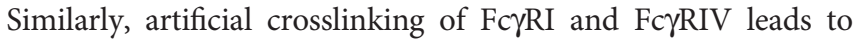
increased osteoclast differentiation without affecting their resorbing function in vitro (17). Osteoclast numbers and bone erosion were decreased in $\mathrm{Fc} \gamma \mathrm{RIV}^{-1-}$ mice compared with wild mice in a serum transfer model (17). Fc $\gamma \mathrm{RIIB}^{-/}$mice spontaneously developed osteoporosis, which was reversed by an additional knockout of activating FcyRs (22).

De-sialylated IgGs binding to FcyRs with strong affinity have substantially high stimulatory effects on both murine and human osteoclasts $(127,133)$. In addition, IgGs were less sialylated during inflammation (22). Harre et al. confirmed that the interactions between immune complexes and osteoclasts were related to the degree of IgG sialylation, and only non-sialylated or low-sialylated immune complexes drive osteoclastogenesis. RA patients with low Fc sialylation levels of IgGs have significantly higher bone loss. The pro-osteoclastogenic effect of non-sialylated immune complexes is a common feature of all IgG antibodies (127). A recent study showed that in induced pluripotent stem cell derived mesenchymal stem cell (iMSCs), the sialylation degree of $\operatorname{IgG}$ determines the antibodies directed osteogenic potential by regulating immune responses and osteoclastogenesis (24),but desialylated IgG complexes do not affect arthritis-mediated bone loss (134).

Although the signaling of activating FcyRs mediated by immune complex increases osteoclast differentiation, different results exist for immune complex/FcyR on osteoclastogenesis and osteoclast function (Table 1). Previous studies demonstrated the immune complex-induced inhibition of osteoclastogenesis, which possibly acts via activating FcyRs $(23,139)$. This suggests that Fc $\gamma$ Rs may have dual roles in bone destruction in inflammatory arthritis. High levels of autoantibodies are a characteristic feature of SLE compared with other inflammatory arthritis $(140,141)$. The deposition of autoantibodies or immune complexes causes lupus nephritis (142), skin damage (143), splenomegaly (144), and damage to other organs. Lupus IgG can promote the differentiation of monocytes into DCs (145). These indicate that lupus autoantibodies may also play a protective role in bone destruction in inflammatory arthritis. Recently, our research results (26) demonstrated that jointdeposited lupus IgG induced arthritis without bone erosion by intraarticular injection of lupus IgG in mice. Monocytes/ macrophages and their product TNF $\alpha$ are required for the development of lupus IgG-induced arthritis. To understand the mechanism of lupus IgG-induced arthritis with deficiency of bone erosion, we determined whether lupus IgG inhibited RANKLinduced osteoclastogenesis. We found that lupus IgG directly suppressed RANKL-induced osteoclastogenesis in a dosedependent manner in vitro. The inhibitory effect of lupus IgG on osteoclastogenesis is related to timepoint in lupus IgG and RANKL

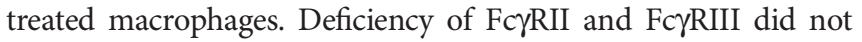
affect the inhibitory effect of lupus IgG on osteoclastogenesis, indicating that the inhibitory effect of lupus IgG on osteoclastogenesis is dependent on Fc $\gamma$ RI. Lupus IgG and RANKL can downregulate the surface expression of Fc $\gamma \mathrm{RI}$ on bone marrow macrophages (20). Research results suggest that lupus IgG inhibits osteoclastogenesis by competitively occupying Fc $\gamma$ RI on monocytes/macrophages and reducing RANKL signaling. The effect of activation or repression of RANKL-induced osteoclastogenesis depends on the extent of Fc $\gamma \mathrm{RI}$ occupancy by IgG. This protective mechanism explains non-destructive arthritis in SLE. In addition, it implies that Fc $\gamma$ RI could be a therapeutic target for bone erosion in inflammatory arthritis.

The deposition of ACPA is important for osteoclastogenesis in RA (146). Different studies have identified that ACPA prevalence is significantly increased in SLE patients with erosive arthritis (16). Recent studies have explored the direct effect of ACPA-mediated bone erosion. ACPA IgG together with their citrullinated antigens forms immune complexes that 
TABLE 1 | Different roles of FcyRs in arthritis and bone destruction.

\begin{tabular}{|c|c|c|c|c|}
\hline $\begin{array}{l}\text { FçR } \\
\text { subtype }\end{array}$ & Animal model & Function & Mechanism & Reference \\
\hline \multirow[t]{2}{*}{ Fc $\gamma R l$} & $\mathrm{ClA}$; K/BxN arthritis & activation & involving in the early arthritis pathology & $(18)$ \\
\hline & lupus-like arthritis; & $\begin{array}{l}\text { activation OR } \\
\text { inhibition }\end{array}$ & depending on the extent of FcyRl occupancy by lgG and RANKL & (26) \\
\hline \multirow[t]{2}{*}{ Fc $\gamma R \| A$} & $\mathrm{CIA}$; K/BxN arthritis & activation & crosstalking with $\mathrm{C5a}$ & $(107,135)$ \\
\hline & & & $\begin{array}{l}\text { receptor; driving the osteoclastogenesis independent of RANKL and inflammatory } \\
\text { cytokines by binding to IgG-ICs }\end{array}$ & \\
\hline FC $\gamma R \| B$ & $\begin{array}{l}\text { AIA; CIA; lupus-like disease in } \\
\text { FcyRIIB-/- mice }\end{array}$ & inhibition & inhibition of FcyRI/III; efficient clearance and endocytosis of ICs & $\begin{array}{c}(18,89,136 \\
137)\end{array}$ \\
\hline FçRIII & $\mathrm{CIA} ; \mathrm{K} / \mathrm{BxN}$ arthritis & activation & being required for early arthritis onset & $(18,35)$ \\
\hline FcyRIV & AlA; K/BxN arthritis & activation & $\begin{array}{l}\text { cross-linking with ICs directly; inducing the influx of S100A8/A9-producing } \\
\text { neutrophils into the arthritic joint. }\end{array}$ & $(5,17,35)$ \\
\hline \multirow[t]{4}{*}{ Unclassified } & $\mathrm{K} / \mathrm{BxN}$ arthritis & inhibition & $\begin{array}{l}\text { activating FcyRs, but not FcyRIIB mediate IC-induced inhibition of } \\
\text { osteoclastogenesis }\end{array}$ & (23) \\
\hline & CIA; IC-induced bone destruction & $\begin{array}{l}\text { activation OR } \\
\text { inhibition }\end{array}$ & 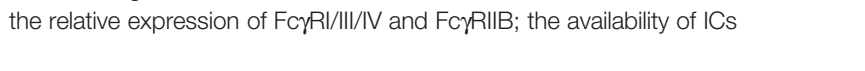 & $(22)$ \\
\hline & $\mathrm{ClA}$ & $\begin{array}{l}\text { activation OR } \\
\text { inhibition }\end{array}$ & the degree of IgG sialylation determines the effect of FcyRs & $(127)$ \\
\hline & TNF-induced osteolysis model & inhibition & $\begin{array}{l}\text { cross-linking of FcyRs with IVIG suppresses osteoclastogenesis by inducing A20 } \\
\text { expression. }\end{array}$ & $(138)$ \\
\hline
\end{tabular}

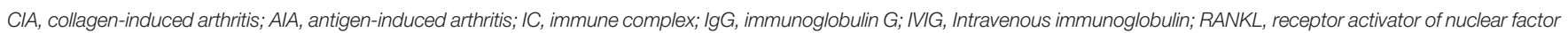
kappa-B ligand; TNF, tumor necrosis factor.

stimulate immune cells via their interaction with Fc $\gamma$ Rs $(93,147)$. By using polyclonal ACPAs purified from ACPA-containing serum of RA patients, Harre et al. provided the first validation that ACPAs can directly promote osteoclast differentiation and activation (7). ACPA IgG might affect osteoclastogenesis by the activation of Fc receptors on osteoclasts directly. IgG Fc sialylation is crucial for immune complex-osteoclast interactions (127). Besides, ACPA IgG is shown less sialylated than random IgG (148). There are other published papers regarding the detailed mechanisms of ACPA's direct regulation, but the exact mechanism of ACPA's direct effect on erosion remains unclear (149-152).

\section{Fc $\gamma R$ IMMUNOTHERAPY}

The crucial role of Fc $\gamma$ Rs in both inflammatory arthritis and bone erosion may offer a promising therapeutic target for bone destruction in inflammatory arthritis. One indirect mechanism involves the neutralization of autoimmune IgG Fc by soluble Fc $\gamma$ Rs, These drugs include the recombinant soluble Fc $\gamma I I B$ receptor SM101 (NCT03851341) and monoclonal antibody targeted the receptors. For example, antagonistic monoclonal antibody against the hFc $\gamma$ RIIIA has been shown to be effective in a patient with immune thrombocytopenia (ITP) refractory to all conventional therapies (153). And human recombinant soluble Fc $\gamma$ RIIB treatment could ameliorate collagen-induced arthritis by reducing immune complexes-stimulated inflammation and joint swelling (154). Besides, recombinant human soluble Fc $\gamma$ RII was evaluated as an effective therapeutic strategy in inhibiting chronic murine lupus pathology (155).

Another mechanism involves the direct blocking of the IgGbinding site on Fc $\gamma$ Rs. Recombinant multimeric Fc fragments with a high affinity for Fc $\gamma$ Rs have been shown to be efficacious in animal models of RA, ITP, and graft-versus-host disease (GVHD) (156). These include PF-06755347 (NCT03275740), CSL730 (NCT04446000) and CSL777 (Preclinical) (157). However, nonspecific crosslinking of activating Fc $\gamma$ Rs could lead to undesired clinical adverse events, and monovalent antibody derivatives, such as Fab, may reduce severe clinical adverse events (158). Up to now, results of above molecules from clinical trials have been promising in autoimmune diseases, but further long-term data are needed $(159,160)$.

Intravenous immunoglobulin (IVIG) treatment is efficient in several different immune disorders $(161,162)$. IVIG consists predominantly of IgG and a small fraction of immune complexes. It exerts anti-inflammatory effects in both humans and animal models by its Fc but not Fab fragments (163). Besides, previous studies confirmed that IVIG could directly inhibits human osteoclastogenesis by suppressing the RANK signaling, the suppressive effect is partly mediated by IgG immune complexes contained within IVIG preparations (138). Our study showed that lupus IgG induced synovial inflammation but inhibited RANKL-induced osteoclastogenesis. The suppressive effect is mediated by the competitive occupation of FcyRI on monocytes/macrophages (26).

\section{CONCLUSIONS AND FUTURE PERSPECTIVES}

Bone erosions are remarkable features in inflammatory arthritis, such as RA, but not in lupus arthritis. Osteoclasts are major cells for bone erosions. Activating Fc $\gamma \mathrm{R}$ containing ITAM motifs is required for RANKL-induced osteoclastogenesis. Fc $\gamma \mathrm{R}$ can effectively regulate inflammatory arthritis and bone erosions. Based on published studies, we conclude that Fc $\gamma \mathrm{R}$ may have dual roles in osteoclastogenesis. The effect of activating and inhibiting 
osteoclastogenesis depends on the extent of Fc $\gamma \mathrm{RI}$ occupancy by IgG and RANKL, respectively. Specific IgG molecules or Fc fragments with a high affinity for Fc $\gamma \mathrm{RI}$ designed to occupy Fc $\gamma \mathrm{RI}$ may exert the inhibitory effect on bone erosion. The sialylation level of IgG Fc binding to FcyRs needs to be taken into account as well. A deeper understanding of Fc $\gamma$ Rs involved in physiological and pathological osteoclastogenesis will be valuable in identifying new targets and developing potential therapeutic strategies for inflammatory arthritis.

\section{DATA AVAILABILITY STATEMENT}

The raw data supporting the conclusions of this article will be made available by the authors, without undue reservation.

\section{REFERENCES}

1. Ledingham J, Snowden N, Ide Z. Diagnosis and Early Management of Inflammatory Arthritis. BMJ (2017) 358:j3248. doi: 10.1136/bmj.j3248

2. Firestein GS. Evolving Concepts of Rheumatoid Arthritis. Nature (2003) 423:356-61. doi: 10.1038/nature01661

3. Symmons D, Turner G, Webb R, Asten P, Barrett E, Lunt M, et al. The Prevalence of Rheumatoid Arthritis in the United Kingdom: New Estimates for a New Century. Rheumatol (Oxford) (2002) 41:793-800. doi: 10.1093/ rheumatology/41.7.793

4. Lee DM, Weinblatt ME. Rheumatoid Arthritis. Lancet (2001) 358:903-11. doi: 10.1016/S0140-6736(01)06075-5

5. Di Ceglie I, Kruisbergen NNL, van den Bosch MHJ, van Lent P. Fc-gamma Receptors and S100A8/A9 Cause Bone Erosion During Rheumatoid Arthritis. Do They Act as Partners in Crime? Rheumatol (Oxford) (2019) 58:1331-43. doi: 10.1093/rheumatology/kez218

6. Cipolletta E, Smerilli G, Di Matteo A, Di Battista J, Di Carlo M, Grassi W, et al. The Sonographic Identification of Cortical Bone Interruptions in Rheumatoid Arthritis: A Morphological Approach. Ther Adv Musculoskelet Dis (2021) 13:1759720x211004326. doi: 10.1177/1759720x211004326

7. Harre U, Georgess D, Bang H, Bozec A, Axmann R, Ossipova E, et al. Induction of Osteoclastogenesis and Bone Loss by Human Autoantibodies Against Citrullinated Vimentin. J Clin Invest (2012) 122:1791-802. doi: 10.1172/JCI60975

8. Beringer A, Miossec P. Systemic Effects of IL-17 in Inflammatory Arthritis. Nat Rev Rheumatol (2019) 15:491-501. doi: 10.1038/s41584-019-0243-5

9. Crowson CS, Matteson EL, Myasoedova E, Michet CJ, Ernste FC, Warrington KJ, et al. The Lifetime Risk of Adult-Onset Rheumatoid Arthritis and Other Inflammatory Autoimmune Rheumatic Diseases. Arthritis Rheum J Clin Invest (2011) 63:633-9. doi: 10.1002/art.30155

10. Kaul A, Gordon C, Crow MK, Touma Z, Urowitz MB, van Vollenhoven R, et al. Systemic Lupus Erythematosus. Nat Rev Dis Primers (2016) 2:16039. doi: 10.1038/nrdp.2016.39

11. Grossman JM. Lupus Arthritis. Best Pract Res Clin Rheumatol (2009) 23:495-506. doi: 10.1016/j.berh.2009.04.003

12. Mahmoud K, Zayat A, Vital EM. Musculoskeletal Manifestations of Systemic Lupus Erythmatosus. Curr Opin Rheumatol (2017) 29:486-92. doi: 10.1097/ BOR.0000000000000421

13. Esdaile JM, Danoff D, Rosenthall L, Gutkowski A. Deforming Arthritis in Systemic Lupus Erythematosus. Ann Rheum Dis (1981) 40:124-6. doi: 10.1136/ard.40.2.124

14. Grigor R, Edmonds J, Lewkonia R, Bresnihan B, Hughes GR. Systemic Lupus Erythematosus. A Prospective Analysis. Ann Rheum Dis (1978) 37:121-8. doi: 10.1136/ard.37.2.121

15. Bouchedoub Y, Djenouhat K, Rachedi N, Babasaci R, Ould Ali L, Salah K, et al. Association of Markers of Rheumatoid Arthritis in Lupus. Is it a Rhupus? Annales biologie clinique (2020) 78:201-5. doi: 10.1684/ abc. 2020.1518

\section{AUTHOR CONTRIBUTIONS}

$\mathrm{YZ}$ and G-MD designed the manuscript and figures. YZ and G-MD drafted the manuscript and approved the final version of the manuscript. G-MD revised the final version of the manuscript critically. All authors contributed to the article and approved the submitted version.

\section{FUNDING}

This study was supported by the initiating fund of Union Hospital, Tongji Medical College, Huazhong University of Science and Technology (G-MD, 02.03.2018-41).

16. Budhram A, Chu R, Rusta-Sallehy S, Ioannidis G, Denburg JA, Adachi JD, et al. Anti-Cyclic Citrullinated Peptide Antibody as a Marker of Erosive Arthritis in Patients With Systemic Lupus Erythematosus: A Systematic Review and Meta-Analysis. Lupus (2014) 23:1156-63. doi: 10.1177/ 0961203314540967

17. Seeling M, Hillenhoff U, David JP, Schett G, Tuckermann J, Lux A, et al. Inflammatory Monocytes and Fcgamma Receptor IV on Osteoclasts Are Critical for Bone Destruction During Inflammatory Arthritis in Mice. Proc Natl Acad Sci USA (2013) 110:10729-34. doi: 10.1073/pnas.1301001110

18. Boross P, van Lent PL, Martin-Ramirez J, van der Kaa J, Mulder MH, Claassens JW, et al. Destructive Arthritis in the Absence of Both FcgammaRI and Fcgammariii. J Immunol (2008) 180:5083-91. doi: 10.4049/ jimmunol.180.7.5083

19. Ji H, Ohmura K, Mahmood U, Lee DM, Hofhuis FM, Boackle SA, et al. Arthritis Critically Dependent on Innate Immune System Players. Immunity (2002) 16:157-68. doi: 10.1016/s1074-7613(02)00275-3

20. Kleinau S, Martinsson P, Heyman B. Induction and Suppression of Collagen-Induced Arthritis Is Dependent on Distinct Fcgamma Receptors. J Exp Med (2000) 191:1611-6. doi: 10.1084/jem.191.9.1611

21. van Lent PL, Grevers L, Lubberts E, de Vries TJ, Nabbe KC, Verbeek S, et al. Fcgamma Receptors Directly Mediate Cartilage, But Not Bone, Destruction in Murine Antigen-Induced Arthritis: Uncoupling of Cartilage Damage From Bone Erosion and Joint Inflammation. Arthritis Rheum (2006) 54:3868-77. doi: 10.1002/art.22253

22. Negishi-Koga T, Gober HJ, Sumiya E, Komatsu N, Okamoto K, Sawa S, et al. Immune Complexes Regulate Bone Metabolism Through FcRgamma Signalling. Nat Commun (2015) 6:6637. doi: 10.1038/ncomms7637

23. Grevers LC, de Vries TJ, Everts V, Verbeek JS, van den Berg WB. Van Lent Pl. Immune Complex-Induced Inhibition of Osteoclastogenesis is Mediated Via Activating But Not Inhibitory Fcgamma Receptors on Myeloid Precursor Cells. Ann Rheum Dis (2013) 72:278-85. doi: 10.1136/ annrheumdis-2012-201568

24. Wu Q, Yang Y, Xie D, Li S, Liu Y, Shu L, et al. The Sialylation Profile of IgG Determines the Efficiency of Antibody Directed Osteogenic Differentiation of iMSCs by Modulating Local Immune Responses and Osteoclastogenesis. Acta biomaterialia (2020) 114:221-32. doi: 10.1016/ j.actbio.2020.07.055

25. Kamohara A, Hirata H, Xu X, Shiraki M, Yamada S, Zhang JQ, et al. Igg Immune Complexes With Staphylococcus Aureus Protein A Enhance Osteoclast Differentiation and Bone Resorption by Stimulating Fc Receptors and TLR2. Int Immunol (2020) 32:89-104. doi: 10.1093/ intimm/dxz063

26. Qiao W, Ding H, Zuo Y, Jiang L, Zhou J, Han X, et al. Lupus IgG Deposition Causes Arthritis But Inhibits Bone Destruction Through Competitive Occupation of FcgammaRI and Reduced RANKL Signalling. Clin Transl Immunol (2020) 9:e1174. doi: 10.1002/cti2.1174

27. Nimmerjahn F, Ravetch JV. Fcgamma Receptors as Regulators of Immune Responses. Nat Rev Immunol (2008) 8:34-47. doi: 10.1038/nri2206 
28. Nimmerjahn F, Ravetch JV. Fc Gamma Receptors: Old Friends and New Family Members. Immunity (2006) 24:19-28. doi: 10.1016/j.immuni. 2005.11.010

29. Nimmerjahn F, Bruhns P, Horiuchi K, Ravetch JV. FcgammaRIV: A Novel FcR With Distinct IgG Subclass Specificity. Immunity (2005) 23:41-51. doi: 10.1016/j.immuni.2005.05.010

30. Nimmerjahn F, Ravetch JV. Divergent Immunoglobulin G Subclass Activity Through Selective Fc Receptor Binding. Science (2005) 310:1510-2. doi: $10.1126 /$ science. 1118948

31. Ravetch JV, Kinet JP. Fc Receptors. Annu Rev Immunol (1991) 9:457-92. doi: 10.1146/annurev.iy.09.040191.002325

32. Hulett MD, Hogarth PM. Molecular Basis of Fc Receptor Function. Adv Immunol (1994) 57:1-127. doi: 10.1016/s0065-2776(08)60671-9

33. Kim N, Takami M, Rho J, Josien R, Choi Y. A Novel Member of the Leukocyte Receptor Complex Regulates Osteoclast Differentiation. J Exp Med (2002) 195:201-9. doi: 10.1084/jem.20011681

34. Bruhns P. Properties of Mouse and Human IgG Receptors and Their Contribution to Disease Models. Blood (2012) 119:5640-9. doi: 10.1182/ blood-2012-01-380121

35. Mancardi DA, Jonsson F, Iannascoli B, Khun H, Van Rooijen N, Huerre M, et al. Cutting Edge: The Murine High-Affinity IgG Receptor FcgammaRIV Is Sufficient for Autoantibody-Induced Arthritis. J Immunol (2011) 186:1899903. doi: 10.4049/jimmunol.1003642

36. Nimmerjahn F, Lux A, Albert H, Woigk M, Lehmann C, Dudziak D, et al. FcgammaRIV Deletion Reveals Its Central Role for IgG2a and IgG2b Activity In Vivo. Proc Natl Acad Sci USA (2010) 107:19396-401. doi: 10.1073/pnas.1014515107

37. Mechetina LV, Najakshin AM, Volkova OY, Guselnikov SV, Faizulin RZ, Alabyev BY, et al. FCRL, a Novel Member of the Leukocyte Fc Receptor Family Possesses Unique Structural Features. Eur J Immunol (2002) 32:8796. doi: 10.1002/1521-4141(200201)32:1<87::AID-IMMU87>3.0.CO;2-\#

38. Ravetch JV, Lanier LL. Immune Inhibitory Receptors. Science (2000) 290:849. doi: $10.1126 /$ science. 290.5489 .84

39. Daeron M. Fc Receptor Biology. Annu Rev Immunol (1997) 15:203-34. doi: 10.1146/annurev.immunol.15.1.203

40. Amigorena S, Bonnerot C, Drake JR, Choquet D, Hunziker W, Guillet JG, et al. Cytoplasmic Domain Heterogeneity and Functions of IgG Fc Receptors in B Lymphocytes. Science (1992) 256:1808-12. doi: 10.1126/science. 1535455

41. Ono M, Bolland S, Tempst P, Ravetch JV. Role of the Inositol Phosphatase SHIP in Negative Regulation of the Immune System by the Receptor Fc (Gamma)RIIB. Nature (1996) 383:263-6. doi: 10.1038/383263a0

42. Daeron M, Jaeger S, Du Pasquier L, Vivier E. Immunoreceptor TyrosineBased Inhibition Motifs: A Quest in the Past and Future. Immunol Rev (2008) 224:11-43. doi: 10.1111/j.1600-065X.2008.00666.x

43. Smith KG, Clatworthy MR. FcgammaRIIB in Autoimmunity and Infection: Evolutionary and Therapeutic Implications. Nat Rev Immunol (2010) 10:328-43. doi: $10.1038 /$ nri2762

44. Takai T. Roles of Fc Receptors in Autoimmunity. Nat Rev Immunol (2002) 2:580-92. doi: $10.1038 /$ nri856

45. Blank U, Launay P, Benhamou M, Monteiro RC. Inhibitory Itams as Novel Regulators of Immunity. Immunol Rev (2009) 232:59-71. doi: 10.1111/ j.1600-065X.2009.00832.X

46. Pasquier B, Launay P, Kanamaru Y, Moura IC, Pfirsch S, Ruffie C, et al. Identification of FcalphaRI as an Inhibitory Receptor That Controls Inflammation: Dual Role of FcRgamma Itam. Immunity (2005) 22:31-42. doi: 10.1016/j.immuni.2004.11.017

47. Hamerman JA, Tchao NK, Lowell CA, Lanier LL. Enhanced Toll-Like Receptor Responses in the Absence of Signaling Adaptor DAP12. Nat Immunol (2005) 6:579-86. doi: 10.1038/ni1204

48. Li X, Ptacek TS, Brown EE, Edberg JC. Fcgamma Receptors: Structure, Function and Role as Genetic Risk Factors in SLE. Genes Immun (2009) 10:380-9. doi: 10.1038/gene.2009.35

49. Selvaraj P, Carpen O, Hibbs ML, Springer TA. Natural Killer Cell and Granulocyte Fc Gamma Receptor III (CD16) Differ in Membrane Anchor and Signal Transduction. J Immunol (1989) 143:3283-8.

50. Selvaraj P, Rosse WF, Silber R, Springer TA. The Major Fc Receptor in Blood has a Phosphatidylinositol Anchor and Is Deficient in Paroxysmal Nocturnal Haemoglobinuria. Nature (1988) 333:565-7. doi: 10.1038/333565a0
51. Steffen U, Schett G, Bozec A. How Autoantibodies Regulate Osteoclast Induced Bone Loss in Rheumatoid Arthritis. Front Immunol 4.71 (2019) 10:1483. doi: 10.3389/fimmu.2019.01483

52. Ben Mkaddem S, Benhamou M, Monteiro RC. Understanding Fc Receptor Involvement in Inflammatory Diseases: From Mechanisms to New Therapeutic Tools. Front Immunol (2019) 10:811. doi: 10.3389/fimmu. 2019.00811

53. Hepburn AL, Mason JC, Davies KA. Expression of Fcgamma and Complement Receptors on Peripheral Blood Monocytes in Systemic Lupus Erythematosus and Rheumatoid Arthritis. Rheumatol (Oxford) (2004) 43:547-54. doi: 10.1093/rheumatology/keh112

54. Amoruso A, Sola D, Rossi L, Obeng JA, Fresu LG, Sainaghi PP, et al. Relation Among Anti-Rheumatic Drug Therapy, CD14(+)CD16(+) Blood Monocytes and Disease Activity Markers (DAS28 and US7 Scores) in Rheumatoid Arthritis: A Pilot Study. Pharmacol Res (2016) 107:308-14. doi: 10.1016/j.phrs.2016.03.034

55. Rossol M, Kraus S, Pierer M, Baerwald C, Wagner U. The CD14(Bright) CD16+ Monocyte Subset Is Expanded in Rheumatoid Arthritis and Promotes Expansion of the Th17 Cell Population. Arthritis Rheum (2012) 64:671-7. doi: 10.1002/art.33418

56. Tsukamoto M, Seta N, Yoshimoto K, Suzuki K, Yamaoka K, Takeuchi T. CD14(Bright)CD16+ Intermediate Monocytes are Induced by interleukin10 and Positively Correlate With Disease Activity in Rheumatoid Arthritis. Arthritis Res Ther (2017) 19:28. doi: 10.1186/s13075-016-1216-6

57. Torsteinsdottir I, Arvidson NG, Hallgren R, Hakansson L. Monocyte Activation in Rheumatoid Arthritis (RA): Increased Integrin, Fc Gamma and Complement Receptor Expression and the Effect of Glucocorticoids. Clin Exp Immunol (1999) 115:554-60. doi: 10.1046/j.1365-2249. 1999.00817.x

58. Matt $\mathrm{P}$, Lindqvist U, Kleinau S. Elevated Membrane and Soluble Cd64: A Novel Marker Reflecting Altered Fcgammar Function and Disease in Early Rheumatoid Arthritis That Can be Regulated by Anti-Rheumatic Treatment. PloS One (2015) 10:e0137474. doi: 10.1371/journal.pone.0137474

59. Blom AB, Radstake TR, Holthuysen AE, Sloetjes AW, Pesman GJ, Sweep FG, et al. Increased Expression of Fcgamma Receptors II and III on Macrophages of Rheumatoid Arthritis Patients Results in Higher Production of Tumor Necrosis Factor Alpha and Matrix Metalloproteinase. Arthritis Rheum (2003) 48:1002-14. doi: 10.1002/art.10871

60. Magnusson SE, Engstrom M, Jacob U, Ulfgren AK, Kleinau S. High Synovial Expression of the Inhibitory FcgammaRIIb in Rheumatoid Arthritis. Arthritis Res Ther (2007) 9:R51. doi: 10.1186/ar2206

61. Di Ceglie I, Ascone G, Cremers NAJ, Sloetjes AW, Walgreen B, Vogl T, et al. Fcgamma Receptor-Mediated Influx of S100A8/A9-Producing Neutrophils as Inducer of Bone Erosion During Antigen-Induced Arthritis. Arthritis Res Ther4.14 (2018) 20:80. doi: 10.1186/s13075-018-1584-1

62. Jovanovic V, Dai X, Lim YT, Kemeny DM, MacAry PA. Fc Gamma Receptor Biology and Systemic Lupus Erythematosus. Int J Rheum Dis (2009) 12:2938. doi: 10.1111/j.1756-185X.2009.01426.x

63. Kaifu T, Nakamura A. Polymorphisms of Immunoglobulin Receptors and the Effects on Clinical Outcome in Cancer Immunotherapy and Other Immune Diseases: A General Review. Int Immunol (2017) 29:319-25. doi: 10.1093/intimm/dxx041

64. Morgan AW, Griffiths B, Ponchel F, Montague BM, Ali M, Gardner PP, et al. Fcgamma Receptor Type IIIA is Associated With Rheumatoid Arthritis in Two Distinct Ethnic Groups. Arthritis Rheum (2000) 43:2328-34. doi: 10.1002/1529-0131(200010)43:10<2328::AID-ANR21>3.0.CO;2-Z

65. Morgan AW, Keyte VH, Babbage SJ, Robinson JI, Ponchel F, Barrett JH, et al. FcgammaRIIIA-158V and Rheumatoid Arthritis: A Confirmation Study. Rheumatol (Oxford) (2003) 42:528-33. doi: 10.1093/rheumatology/keg169

66. Koene HR, Kleijer M, Algra J, Roos D, von dem Borne AE, de Haas M. Fc gammaRIIIa-158V/F Polymorphism Influences the Binding of IgG by Natural Killer Cell Fc gammaRIIIa, Independently of the Fc gammaRIIIa48L/R/H Phenotype. Blood (1997) 90:1109-14. doi: 10.1182/blood.V90. 3.1109.1109_1109_1114

67. Sun Y, Mo L, Feng X, Yang D, Tan T, Zeng L, et al. Association of Fcgamma Receptor Type 2A and 3A Genotypes With Rheumatoid Arthritis in Chinese Population. Pharmacogenomics (2017) 18:255-64. doi: 10.2217/pgs-20160159 
68. Lee YH, Bae SC, Song GG. FCGR2A, Fcgr3a, FCGR3B Polymorphisms and Susceptibility to Rheumatoid Arthritis: A Meta-Analysis. Clin Exp Rheumatol (2015) 33:647-54.

69. Avila-Pedretti G, Tornero J, Fernandez-Nebro A, Blanco F, Gonzalez-Alvaro I, Canete JD, et al. Variation at FCGR2A and Functionally Related Genes Is Associated With the Response to anti-TNF Therapy in Rheumatoid Arthritis. PloS One (2015) 10:e0122088. doi: 10.1371/journal.pone.0122088

70. Ben Mkaddem S, Hayem G, Jönsson F, Rossato E, Boedec E, Boussetta T, et al. Shifting Fcrriia-ITAM From Activation to Inhibitory Configuration Ameliorates Arthritis. J Clin Invest (2014) 124:3945-59. doi: 10.1172/ jci74572

71. Chen JY, Wang CM, Ma CC, Luo SF, Edberg JC, Kimberly RP, et al. Association of a Transmembrane Polymorphism of Fcgamma Receptor IIb (FCGR2B) With Systemic Lupus Erythematosus in Taiwanese Patients. Arthritis Rheum (2006) 54:3908-17. doi: 10.1002/art.22220

72. Chen JY, Wang CM, Chang SW, Cheng CH, Wu YJ, Lin JC, et al. Association of FCGR3A and FCGR3B Copy Number Variations With Systemic Lupus Erythematosus and Rheumatoid Arthritis in Taiwanese Patients. Arthritis Rheumatol (2014) 66:3113-21. doi: 10.1002/art.38813

73. Ceccarelli F, Perricone C, Borgiani P, Ciccacci C, Rufini S, Cipriano E, et al. Genetic Factors in Systemic Lupus Erythematosus: Contribution to Disease Phenotype. J Immunol Res (2015) 2015:745647. doi: 10.1155/2015/745647

74. Lehrnbecher T, Foster CB, Zhu S, Leitman SF, Goldin LR, Huppi K, et al. Variant Genotypes of the Low-Affinity Fcgamma Receptors in Two Control Populations and a Review of Low-Affinity Fcgamma Receptor Polymorphisms in Control and Disease Populations. Blood (1999) 94:4220-32. doi: 10.1182/blood.V94.12.4220

75. Tsang ASMW, Nagelkerke SQ, Bultink IE, Geissler J, Tanck MW, Tacke CE, et al. Fc-Gamma Receptor Polymorphisms Differentially Influence Susceptibility to Systemic Lupus Erythematosus and Lupus Nephritis. Rheumatol (Oxford) (2016) 55:939-48. doi: 10.1093/rheumatology/kev433

76. el Bannoudi H, Ioan-Facsinay A, Toes RE. Bridging Autoantibodies and Arthritis: The Role of Fc Receptors. Curr Top Microbiol Immunol (2014) 382:303-19. doi: 10.1007/978-3-319-07911-0_14

77. Boross P, Verbeek JS. The Complex Role of Fcgamma Receptors in the Pathology of Arthritis. Springer Semin Immunopathol (2006) 28:339-50. doi: 10.1007/s00281-006-0049-9

78. Kagari T, Tanaka D, Doi H, Shimozato T. Essential Role of Fc Gamma Receptors in Anti-Type II Collagen Antibody-Induced Arthritis. J Immunol (2003) 170:4318-24. doi: 10.4049/jimmunol.170.8.4318

79. Kaplan CD, O'Neill SK, Koreny T, Czipri M, Finnegan A. Development of Inflammation in Proteoglycan-Induced Arthritis is Dependent on Fc Gamma R Regulation of the Cytokine/Chemokine Environment. J Immunol (2002) 169:5851-9. doi: 10.4049/jimmunol.169.10.5851

80. Blom AB, van Lent PL, van Vuuren H, Holthuysen AE, Jacobs C, van de Putte LB, et al. Fc Gamma R Expression on Macrophages is Related to Severity and Chronicity of Synovial Inflammation and Cartilage Destruction During Experimental Immune-Complex-Mediated Arthritis (ICA). Arthritis Res (2000) 2:489-503. doi: 10.1186/ar131

81. van Lent PL, van Vuuren AJ, Blom AB, Holthuysen AE, van de Putte LB, van de Winkel JG, et al. Role of Fc Receptor Gamma Chain in Inflammation and Cartilage Damage During Experimental Antigen-Induced Arthritis. Arthritis Rheum (2000) 43:740-52. doi: 10.1002/1529-0131(200004)43:4<740::AIDANR4 $>3.0 . C O ; 2-0$

82. Corr M, Crain B. The Role of FcgammaR Signaling in the K/B X N Serum Transfer Model of Arthritis. J Immunol (2002) 169:6604-9. doi: 10.4049/ jimmunol.169.11.6604

83. Díaz de Ståhl T, Andrén M, Martinsson P, Verbeek JS, Kleinau S. Expression of FcgammaRIII is Required for Development of Collagen-Induced Arthritis. Eur J Immunol (2002) 32:2915-22. doi: 10.1002/1521-4141 (2002010)32:10<2915::Aid-immu2915>3.0.Co;2-4

84. Kaplan CD, Cao Y, Verbeek JS, Tunyogi-Csapo M, Finnegan A. Development of Proteoglycan-Induced Arthritis is Critically Dependent on Fcgamma Receptor Type III Expression. Arthritis Rheum (2005) 52:1612-9. doi: 10.1002/art.21030

85. Nabbe KC, Blom AB, Holthuysen AE, Boross P, Roth J, Verbeek S, et al. Coordinate Expression of Activating Fc Gamma Receptors I and III and Inhibiting Fc Gamma Receptor Type II in the Determination of Joint
Inflammation and Cartilage Destruction During Immune ComplexMediated Arthritis. Arthritis Rheum (2003) 48:255-65. doi: 10.1002/ art.10721

86. van Lent PL, Nabbe K, Blom AB, Holthuysen AE, Sloetjes A, van de Putte LB, et al. Role of Activatory Fc Gamma RI and Fc Gamma RIII and Inhibitory Fc Gamma RII in Inflammation and Cartilage Destruction During Experimental Antigen-Induced Arthritis. Am J Pathol (2001) 159:2309-20. doi: 10.1016/s0002-9440(10)63081-7

87. Radstake TR, Franke B, Wenink MH, Nabbe KC, Coenen MJ, Welsing P, et al. The Functional Variant of the Inhibitory Fcgamma Receptor IIb (CD32B) is Associated With the Rate of Radiologic Joint Damage and Dendritic Cell Function in Rheumatoid Arthritis. Arthritis Rheum (2006) 54:3828-37. doi: 10.1002/art.22275

88. Nandakumar KS, Andren M, Martinsson P, Bajtner E, Hellstrom S, Holmdahl R, et al. Induction of Arthritis by Single Monoclonal IgG AntiCollagen Type II Antibodies and Enhancement of Arthritis in Mice Lacking Inhibitory Fcgammariib. Eur J Immunol (2003) 33:2269-77. doi: 10.1002/ eji.200323810

89. Yuasa T, Kubo S, Yoshino T, Ujike A, Matsumura K, Ono M, et al. Deletion of Fcgamma Receptor IIB Renders H-2(b) Mice Susceptible to CollagenInduced Arthritis. J Exp Med (1999) 189:187-94. doi: 10.1084/jem.189.1.187

90. Yilmaz-Elis AS, Ramirez JM, Asmawidjaja P, van der Kaa J, Mus AM, Brem MD, et al. FcgammaRIIb on Myeloid Cells Rather Than on B Cells Protects From Collagen-Induced Arthritis. I Immunol (2014) 192:5540-7. doi: 10.4049 /jimmunol.1303272

91. Brownlie RJ, Lawlor KE, Niederer HA, Cutler AJ, Xiang Z, Clatworthy MR, et al. Distinct Cell-Specific Control of Autoimmunity and Infection by Fcgammariib. J Exp Med (2008) 205:883-95. doi: 10.1084/jem.20072565

92. Tan Sardjono C, Mottram PL, van de Velde NC, Powell MS, Power D, Slocombe RF, et al. Development of Spontaneous Multisystem Autoimmune Disease and Hypersensitivity to Antibody-Induced Inflammation in Fcgamma Receptor IIa-transgenic Mice. Arthritis Rheum (2005) 52:32209. doi: 10.1002/art.21344

93. Anquetil F, Clavel C, Offer G, Serre G, Sebbag M. Igm and IgA Rheumatoid Factors Purified From Rheumatoid Arthritis Sera Boost the Fc Receptor- and Complement-Dependent Effector Functions of the Disease-Specific AntiCitrullinated Protein Autoantibodies. J Immunol (2015) 194:3664-74. doi: 10.4049/jimmunol.1402334

94. Clavel C, Ceccato L, Anquetil F, Serre G, Sebbag M. Among Human Macrophages Polarised to Different Phenotypes, the M-CSF-oriented Cells Present the Highest Pro-Inflammatory Response to the Rheumatoid Arthritis-Specific Immune Complexes Containing ACPA. Ann Rheum Dis (2016) 75:2184-91. doi: 10.1136/annrheumdis-2015-208887

95. Laurent L, Clavel C, Lemaire O, Anquetil F, Cornillet M, Zabraniecki L, et al. Fcgamma Receptor Profile of Monocytes and Macrophages From Rheumatoid Arthritis Patients and Their Response to Immune Complexes Formed With Autoantibodies to Citrullinated Proteins. Ann Rheum Dis (2011) 70:1052-9. doi: 10.1136/ard.2010.142091

96. Machold KP, Stamm TA, Nell VP, Pflugbeil S, Aletaha D, Steiner G, et al. Very Recent Onset Rheumatoid Arthritis: Clinical and Serological Patient Characteristics Associated With Radiographic Progression Over the First Years of Disease. Rheumatol (Oxford) (2007) 46:342-9. doi: 10.1093/ rheumatology/kel237

97. Clavel C, Nogueira L, Laurent L, Iobagiu C, Vincent C, Sebbag M, et al. Induction of Macrophage Secretion of Tumor Necrosis Factor Alpha Through Fcgamma Receptor IIa Engagement by Rheumatoid ArthritisSpecific Autoantibodies to Citrullinated Proteins Complexed With Fibrinogen. Arthritis Rheum (2008) 58:678-88. doi: 10.1002/art.23284

98. Liu Y, Masuda E, Blank MC, Kirou KA, Gao X, Park MS, et al. CytokineMediated Regulation of Activating and Inhibitory Fc Gamma Receptors in Human Monocytes. J Leukoc Biol (2005) 77:767-76. doi: 10.1189/jlb.0904532

99. Allen E, Bakke AC, Purtzer MZ, Deodhar A. Neutrophil CD64 Expression: Distinguishing Acute Inflammatory Autoimmune Disease From Systemic Infections. Ann Rheum Dis (2002) 61:522-5. doi: 10.1136/ard.61.6.522

100. Hussein OA, El-Toukhy MA, El-Rahman HS. Neutrophil CD64 Expression in Inflammatory Autoimmune Diseases: Its Value in Distinguishing Infection From Disease Flare. Immunol Invest (2010) 39:699-712. doi: 10.3109/08820139.2010.491520 
101. Fjaertoft G, Hakansson LD, Pauksens K, Sisask G, Venge P. Neutrophil Cd64 (FcgammaRI) Expression Is a Specific Marker of Bacterial Infection: A Study on the Kinetics and the Impact of Major Surgery. Scand J Infect Dis (2007) 39:525-35. doi: 10.1080/00365540601113693

102. Fjaertoft G, Pauksen K, Hakansson L, Xu S, Venge P. Cell Surface Expression of FcgammaRI (CD64) on Neutrophils and Monocytes in Patients With Influenza A, With and Without Complications. Scand J Infect Dis (2005) 37:882-9. doi: 10.1080/00365540500348929

103. Bournazos S, Wang TT, Dahan R, Maamary J, Ravetch JV. Signaling by Antibodies: Recent Progress. Annu Rev Immunol (2017) 35:285-311. doi: 10.1146/annurev-immunol-051116-052433

104. Oppegaard O, Skodvin B, Halse AK, Langeland N. CD64 as a Potential Biomarker in Septic Arthritis. BMC Infect Dis (2013) 13:278. doi: 10.1186/ 1471-2334-13-278

105. Li S, Huang X, Chen Z, Zhong H, Peng Q, Deng Y, et al. Neutrophil CD64 Expression as a Biomarker in the Early Diagnosis of Bacterial Infection: A Meta-Analysis. Int J Infect Dis (2013) 17:e12-23. doi: 10.1016/j.ijid. 2012.07.017

106. Cid J, Aguinaco R, Sanchez R, Garcia-Pardo G, Llorente A. Neutrophil CD64 Expression as Marker of Bacterial Infection: A Systematic Review and MetaAnalysis. J Infect (2010) 60:313-9. doi: 10.1016/j.jinf.2010.02.013

107. Tsuboi N, Ernandez T, Li X, Nishi H, Cullere X, Mekala D, et al. Regulation of Human Neutrophil Fcgamma Receptor IIa by C5a Receptor Promotes Inflammatory Arthritis in Mice. Arthritis Rheum (2011) 63:467-78. doi: 10.1002/art.30141

108. Karsenty G, Wagner EF. Reaching a Genetic and Molecular Understanding of Skeletal Development. Dev Cell (2002) 2:389-406. doi: 10.1016/s15345807(02)00157-0

109. Teitelbaum SL, Ross FP. Genetic Regulation of Osteoclast Development and Function. Nat Rev Genet (2003) 4:638-49. doi: 10.1038/nrg1122

110. Boyle WJ, Simonet WS, Lacey DL. Osteoclast Differentiation and Activation. Nature (2003) 423:337-42. doi: 10.1038/nature01658

111. Theill LE, Boyle WJ, Penninger JM. RANK-L and RANK: T Cells, Bone Loss, and Mammalian Evolution. Annu Rev Immunol (2002) 20:795-823. doi: 10.1146/annurev.immunol.20.100301.064753

112. Xiong J, Piemontese M, Onal M, Campbell J, Goellner JJ, Dusevich V, et al. Osteocytes, Not Osteoblasts or Lining Cells, Are the Main Source of the RANKL Required for Osteoclast Formation in Remodeling Bone. PloS One (2015) 10:e0138189. doi: 10.1371/journal.pone.0138189

113. Nakashima T, Hayashi M, Fukunaga T, Kurata K, Oh-Hora M, Feng JQ, et al. Evidence for Osteocyte Regulation of Bone Homeostasis Through RANKL Expression. Nat Med (2011) 17:1231-4. doi: 10.1038/nm.2452

114. Walsh MC, Choi Y. Biology of the RANKL-RANK-OPG System in Immunity, Bone, and Beyond. Front Immunol (2014) 5:511. doi: 10.3389/ fimmu.2014.00511

115. Terashima A, Takayanagi H. Overview of Osteoimmunology. Calcif Tissue Int (2018) 102:503-11. doi: 10.1007/s00223-018-0417-1

116. Compton JT, Lee FY. A Review of Osteocyte Function and the Emerging Importance of Sclerostin. J Bone Joint Surg Am (2014) 96:1659-68. doi: 10.2106/jbjs.M.01096

117. Takayanagi H, Kim S, Koga T, Nishina H, Isshiki M, Yoshida H, et al. Induction and Activation of the Transcription Factor NFATc1 (NFAT2) Integrate RANKL Signaling in Terminal Differentiation of Osteoclasts. Dev Cell (2002) 3:889-901. doi: 10.1016/s1534-5807(02)00369-6

118. Braun T, Zwerina J. Positive Regulators of Osteoclastogenesis and Bone Resorption in Rheumatoid Arthritis. Arthritis Res Ther (2011) 13:235. doi: $10.1186 / \mathrm{ar} 3380$

119. Koga T, Inui M, Inoue K, Kim S, Suematsu A, Kobayashi E, et al. Costimulatory Signals Mediated by the ITAM Motif Cooperate With RANKL for Bone Homeostasis. Nature (2004) 428:758-63. doi: 10.1038/ nature 02444

120. Ivashkiv LB. Cross-Regulation of Signaling by ITAM-Associated Receptors. Nat Immunol (2009) 10:340-7. doi: 10.1038/ni.1706

121. Mocsai A, Humphrey MB, Van Ziffle JA, Hu Y, Burghardt A, Spusta SC, et al. The Immunomodulatory Adapter Proteins DAP12 and Fc Receptor Gamma-Chain (FcRgamma) Regulate Development of Functional Osteoclasts Through the Syk Tyrosine Kinase. Proc Natl Acad Sci USA (2004) 101:6158-63. doi: 10.1073/pnas.0401602101
122. Kaifu T, Nakahara J, Inui M, Mishima K, Momiyama T, Kaji M, et al. Osteopetrosis and Thalamic Hypomyelinosis With Synaptic Degeneration in DAP12-deficient Mice. J Clin Invest (2003) 111:323-32. doi: 10.1172/ JCI16923

123. Paradowska-Gorycka A, Jurkowska M. Structure, Expression Pattern and Biological Activity of Molecular Complex TREM-2/DAP12. Hum Immunol (2013) 74:730-7. doi: 10.1016/j.humimm.2013.02.003

124. Tsukasaki M, Takayanagi H. Osteoimmunology: Evolving Concepts in BoneImmune Interactions in Health and Disease. Nat Rev Immunol (2019) 19:626-42. doi: 10.1038/s41577-019-0178-8

125. Guerrini MM, Takayanagi H. The Immune System, Bone and RANKL. Arch Biochem Biophys (2014) 561:118-23. doi: 10.1016/j.abb.2014.06.003

126. Harre U, Keppeler H, Ipseiz N, Derer A, Poller K, Aigner M, et al. Moonlighting Osteoclasts as Undertakers of Apoptotic Cells. Autoimmunity (2012) 45:612-9. doi: 10.3109/08916934.2012.719950

127. Harre U, Lang SC, Pfeifle R, Rombouts Y, Fruhbeisser S, Amara K, et al. Glycosylation of Immunoglobulin G Determines Osteoclast Differentiation and Bone Loss. Nat Commun (2015) 6:6651. doi: 10.1038/ncomms7651

128. Kleyer A, Finzel S, Rech J, Manger B, Krieter M, Faustini F, et al. Bone Loss Before the Clinical Onset of Rheumatoid Arthritis in Subjects With Anticitrullinated Protein Antibodies. Ann Rheum Dis (2014) 73:854-60. doi: 10.1136/annrheumdis-2012-202958

129. Kleyer A, Schett G. Arthritis and Bone Loss: A Hen and Egg Story. Curr Opin Rheumatol (2014) 26:80-4. doi: 10.1097/BOR.0000000000000007

130. Onuora S. Osteoimmunology: IgG Immune Complexes Directly Regulate Bone Homeostasis. Nat Rev Rheumatol (2015) 11:257. doi: 10.1038/ nrrheum.2015.51

131. Karsten CM, Kohl J. A Bone to Pick With Fc Gamma Receptors. Ann Transl Med (2015) 3:218. doi: 10.3978/j.issn.2305-5839.2015.07.11

132. Kastbom A, Ahmadi A, Soderkvist P, Skogh T. The 158V Polymorphism of Fc Gamma Receptor Type IIIA in Early Rheumatoid Arthritis: Increased Susceptibility and Severity in Male Patients (the Swedish TIRA Project). Rheumatol (Oxford) (2005) 44:1294-8. doi: 10.1093/rheumatology/kei010

133. Pagan JD, Kitaoka M, Anthony RM. Engineered Sialylation of Pathogenic Antibodies In Vivo Attenuates Autoimmune Disease. Cell (2018) 172:564577 e513. doi: 10.1016/j.cell.2017.11.041

134. Sehic E, Westerlund A, Lagerquist MK, Lerner UH, Carlsten H, Henning P, et al. Immunoglobulin G Complexes Without Sialic Acids Enhance Osteoclastogenesis But do Not Affect Arthritis-Mediated Bone Loss. Scand J Immunol (2021) 93:e13009. doi: 10.1111/sji.13009

135. Zeng KQ, Gong FY, Pan XH, Miao J, Gong Z, Wang J, et al. IgG Immunocomplexes Drive the Differentiation of a Novel Subset of Osteoclasts Independent of RANKL and Inflammatory Cytokines. $J$ Bone Miner Res (2021). doi: 10.1002/jbmr.4281

136. van Lent $\mathrm{P}$, Nabbe KC, Boross $\mathrm{P}$, Blom AB, Roth J, Holthuysen A, et al. The Inhibitory Receptor FcgammaRII Reduces Joint Inflammation and Destruction in Experimental Immune Complex-Mediated Arthritides Not Only by Inhibition of FcgammaRI/III But Also by Efficient Clearance and Endocytosis of Immune Complexes. Am J Pathol (2003) 163:1839-48. doi: 10.1016/s0002-9440(10)63543-2

137. Visitchanakun P, Saiworn W, Jongwattanapisan P, Leelahavanichkul A, Pisitkun P, Lotinun S. Lupus-Like Disease in FcrRIIB(-/-) Mice Induces Osteopenia. Sci Rep (2019) 9:17342. doi: 10.1038/s41598-019-53963-Z

138. Lee MJ, Lim E, Mun S, Bae S, Murata K, Ivashkiv LB, et al. Intravenous Immunoglobulin (Ivig) Attenuates Tnf-Induced Pathologic Bone Resorption and Suppresses Osteoclastogenesis by Inducing A20 Expression. J Cell Physiol (2016) 231:449-58. doi: 10.1002/jcp.25091

139. MacLellan LM, Montgomery J, Sugiyama F, Kitson SM, Thummler K, Silverman GJ, et al. Co-Opting Endogenous Immunoglobulin for the Regulation of Inflammation and Osteoclastogenesis in Humans and Mice. Arthritis Rheum (2011) 63:3897-907. doi: 10.1002/art.30629

140. Tsokos GC. Systemic Lupus Erythematosus. A Disease With a Complex Pathogenesis. Lancet (2001) 358 Suppl:S65. doi: 10.1016/s0140-6736(01) 07077-5

141. Salmon JE, Pricop L. Human Receptors for Immunoglobulin G: Key Elements in the Pathogenesis of Rheumatic Disease. Arthritis Rheum (2001) 44:739-50. doi: 10.1002/1529-0131(200104)44:4<739::AIDANR129>3.0.CO;2-O 
142. Zuniga R, Markowitz GS, Arkachaisri T, Imperatore EA, D’Agati VD, Salmon JE. Identification of IgG Subclasses and C-reactive Protein in Lupus Nephritis: The Relationship Between the Composition of Immune Deposits and FCgamma Receptor Type IIA Alleles. Arthritis Rheum (2003) 48:460-70. doi: 10.1002/art.10930

143. Deng GM, Tsokos GC. Pathogenesis and Targeted Treatment of Skin Injury in SLE. Nat Rev Rheumatol (2015) 11:663-9. doi: 10.1038/nrrheum.2015.106

144. Zhang Q, Xiang L, Zaman MH, Dong W, He G, Deng GM. Predominant Role of Immunoglobulin G in the Pathogenesis of Splenomegaly in Murine Lupus. Front Immunol (2019) 10:3020. doi: 10.3389/fimmu.2019.03020

145. Deng GM, Liu L, Kyttaris VC, Tsokos GC. Lupus Serum IgG Induces Skin Inflammation Through the TNFR1 Signaling Pathway. J Immunol (2010) 184:7154-61. doi: 10.4049/jimmunol.0902514

146. Malmstrom V, Catrina AI, Klareskog L. The Immunopathogenesis of Seropositive Rheumatoid Arthritis: From Triggering to Targeting. Nat Rev Immunol (2017) 17:60-75. doi: 10.1038/nri.2016.124

147. Auréal M, Machuca-Gayet I, Coury F. Rheumatoid Arthritis in the View of Osteoimmunology. Biomolecules (2020) 11:48. doi: 10.3390/biom11010048

148. Scherer HU, van der Woude D, Ioan-Facsinay A, I Bannoudi H, Trouw LA, Wang J, et al. Glycan Profiling of Anti-Citrullinated Protein Antibodies Isolated From Human Serum and Synovial Fluid. Arthritis Rheum (2010) 62:1620-9. doi: 10.1002/art.27414

149. Correction: Autoantibodies to Citrullinated Proteins Induce Joint Pain Independent of Inflammation Via a Chemokine-Dependent Mechanism. Ann Rheum Dis (2019) 78:865. doi: 10.1136/annrheumdis-2015-208094corr1

150. Wigerblad G, Bas DB, Fernades-Cerqueira C, Krishnamurthy A, Nandakumar KS, Rogoz K, et al. Autoantibodies to Citrullinated Proteins Induce Joint Pain Independent of Inflammation Via a ChemokineDependent Mechanism. Ann Rheum Dis (2016) 75:730-8. doi: 10.1136/ annrheumdis-2015-208094

151. Correction: Identification of a Novel Chemokine-Dependent Molecular Mechanism Underlying Rheumatoid Arthritis-Associated AutoantibodyMediated Bone Loss. Ann Rheum Dis (2019) 78:866. doi: 10.1136/ annrheumdis-2015-208093corr1

152. Krishnamurthy A, Joshua V, Haj Hensvold A, Jin T, Sun M, Vivar N, et al. Identification of a Novel Chemokine-Dependent Molecular Mechanism Underlying Rheumatoid Arthritis-Associated Autoantibody-Mediated Bone Loss. Ann Rheum Dis (2016) 75:721-9. doi: 10.1136/annrheumdis-2015-208093

153. Clarkson SB, Bussel JB, Kimberly RP, Valinsky JE, Nachman RL, Unkeless JC. Treatment of Refractory Immune Thrombocytopenic Purpura With an anti-Fc Gamma-Receptor Antibody. N Engl J Med (1986) 314:1236-9. doi: 10.1056/nejm198605083141907

154. Magnusson SE, Andrén M, Nilsson KE, Sondermann P, Jacob U, Kleinau S. Amelioration of Collagen-Induced Arthritis by Human Recombinant Soluble Fcgammariib. Clin Immunol (2008) 127:225-33. doi: 10.1016/ j.clim.2008.02.002
155. Werwitzke S, Trick D, Sondermann P, Kamino K, Schlegelberger B, Kniesch $\mathrm{K}$, et al. Treatment of Lupus-Prone NZB/NZW F1 Mice With Recombinant Soluble Fc Gamma Receptor II (Cd32). Ann Rheum Dis (2008) 67:154-61. doi: 10.1136/ard.2006.068981

156. Jain A, Olsen HS, Vyzasatya R, Burch E, Sakoda Y, Mérigeon EY, et al. Fully Recombinant IgG2a Fc Multimers (Stradomers) Effectively Treat CollagenInduced Arthritis and Prevent Idiopathic Thrombocytopenic Purpura in Mice. Arthritis Res Ther (2012) 14:R192. doi: 10.1186/ar4024

157. Zuercher AW, Spirig R, Baz Morelli A, Rowe T, Käsermann F. Nextgeneration Fc Receptor-Targeting Biologics for Autoimmune Diseases. Autoimmun Rev (2019) 18:102366. doi: 10.1016/j.autrev.2019.102366

158. Yu X, Lazarus AH. Targeting Fc $\gamma$ rs to Treat Antibody-Dependent Autoimmunity. Autoimmun Rev (2016) 15:510-2. doi: 10.1016/j.autrev. 2016.02.006

159. Konstaninova TS, Leonidovna IV, Hellmann A, Kyrcz-Krzemien S, Tillmanns S, Sondermann P, et al. Interim Results From a Phase Ib/Iia Clinical Trial With the Soluble Fc-Gamma IIb Receptor SM101 for the Treatment of Primary Immune Thrombocytopenia. Blood (2012) 120:3388. doi: 10.1182/blood.V120.21.3388.3388

160. Tillmanns S, Kolligs C, D'Cruz DP, Doria A, Hachulla E, Voll RE, et al. SM101, a Novel Recombinant, Soluble, Human Fc Gamma IIB Receptor, in the Treatment of Systemic Lupus Erythematosus: Results of a Double-Blind, Placebo-Controlled Multicenter Study. Arthritis Rheumatol (2014) 66: S1238-8. doi: 10.1002/art.38914

161. Clynes R. Protective Mechanisms of IVIG. Curr Opin Immunol (2007) 19:646-51. doi: 10.1016/j.coi.2007.09.004

162. Nimmerjahn F, Ravetch JV. Anti-Inflammatory Actions of Intravenous Immunoglobulin. Annu Rev Immunol (2008) 26:513-33. doi: 10.1146/ annurev.immunol.26.021607.090232

163. Schwab I, Nimmerjahn F. Intravenous Immunoglobulin Therapy: How Does IgG Modulate the Immune System? Nat Rev Immunol (2013) 13:176-89. doi: $10.1038 /$ nri3401

Conflict of Interest: The authors declare that the research was conducted in the absence of any commercial or financial relationships that could be construed as a potential conflict of interest.

The reviewer PZ declared a shared affiliation with the authors to the handling editor at the time of review.

Copyright (c) 2021 Zuo and Deng. This is an open-access article distributed under the terms of the Creative Commons Attribution License (CC BY). The use, distribution or reproduction in other forums is permitted, provided the original author(s) and the copyright owner(s) are credited and that the original publication in this journal is cited, in accordance with accepted academic practice. No use, distribution or reproduction is permitted which does not comply with these terms. 